\title{
Implementing Integrated Education Policy for On-Reserve Aboriginal Children in British Columbia, 1951-1981
}

\section{Helen Raptis}

\section{ABSTRACT}

In 1951, the Canadian government changed the Indian Act to allow for the integration of previously segregated on-reserve Aboriginal children into the nation's public schools. Although British Columbia's first integration initiatives actually predate the 1951 legislative changes, most on-reserve children did not attend off-reserve public schools until after 1951. As elsewhere in Canada, British Columbia heralded the 1951 legislation with fanfare and optimism. However, three decades later the Union of BC Indian Chiefs issued a policy statement calling for alternative options for Aboriginal children. This paper traces the province's earliest integration initiatives until 1981. It illustrates a complex and dynamic implementation process that changed considerably over time. In particular, it demonstrates the difficulties provincial authorities encounter in attempting to leverage change at the level of individual learners.

\section{RÉSUMÉ}

En 1951, le gouvernement du Canada modifia la Loi des Indiens afin de permettre l'intégration des enfants autochtones, jusque-là ségrégués dans les réserves, aux écoles publiques nationales. Bien que les premières initiatives d'intégration de la Colombie britannique étaient antérieures aux changements législatifs, la plupart des enfants vivant en réserves ne fréquentaient pas les écoles publiques hors réserves avant 1951. Comme partout au Canada, la Colombie britannique annonça la loi avec fanfare et optimisme. Cependant, trois décennies plus tard, l'Union des chefs indiens de la Colombie britannique fit paraître une déclaration de principe demandant que d'autres possibilités soient offertes aux enfants autochtones. Cet article décrit les tentatives d'intégration de la province depuis les débuts jusqu'en 1981. Il met en lumière un processus d'implantation complexe et dynamique qui varia considérablement avec le temps. Il montre notamment les difficultés que rencontrèrent les autorités provinciales dans leurs efforts pour apporter un changement qui soit à la portée de chacun des débutants.

Authority over public schooling in Canada was conferred upon the provinces with the signing of the 1867 British North America Act (now the Constitution Act, 1982), which also granted the Dominion Government jurisdiction over Indian affairs. Thus, until 1951, most Aboriginal children were educated separately from their nonAboriginal peers, first in missionary-run schools, then in industrial, boarding (later 
residential) and day schools managed by various denominational organizations on behalf of the Dominion Government. ${ }^{1}$

Changing post-World War II sentiments about individuals' inherent rights to equality prompted Canada to reconsider such discriminatory practices and, acting on the recommendations of the Special Joint Committee of the Senate and the House of Commons, the federal government adopted a policy of promoting the education of Aboriginal children "in association with other children." This policy was legalized in 1951 with revisions to the Indian Act enabling the Minister of Indian Affairs to enter into agreements with provincial governments, territorial councils, school boards or religious or charitable organizations for the schooling of Aboriginal children living on reserve. ${ }^{3}$

As elsewhere in Canada, British Columbia heralded the 1951 federal integration policy with optimism and fanfare. Newspaper articles and editorial opinions praised the policy shift, arguing that full citizenship for Indian people could only be achieved through integration. ${ }^{4}$ But the dreams of post-war reformers would not last long. Three decades later the Union of BC Indian Chiefs (UBCIC) issued a policy statement calling for the "non-recognition of the public schools as an alternative for the education of Indian children."

Although other scholars have examined post-1951 developments in Aboriginal schooling, the existing body of research generally focuses on federal authorities, laws and policies. ${ }^{6}$ No research to date has examined the development of integrated schooling through the lens of one province's educational authorities. This paper seeks to expand our understanding of integrated schooling in $\mathrm{BC}$ by tracing the province's earliest integration initiatives until 1981 when the UBCIC made its announcement. Several questions guided the trajectory of this study: When did the province first begin to integrate Aboriginal children into its public schools? How did British Columbia's education officials perceive of and implement the federal integration policy? Who negotiated and implemented integration efforts and why? What initiatives were undertaken by the provincial Department (later Ministry) of Education? Why were these initiatives considered to have failed in 1981?

This paper reconstructing British Columbia's integrated schooling initiatives illustrates a complex and dynamic implementation process that changed considerably over time. It also highlights the dilemma provincial authorities face with respect to implementing policy intents which originate outside of educational institutions themselves, far from the reach of those who, ultimately, must translate policies and legislation into administrative and pedagogical practice.

\section{Early Integration Initiatives}

When British Columbia established its public school system in 1872 most Aboriginal children attended nationally-funded, church-administered schools, ${ }^{7}$ although small numbers were scattered throughout some of the province's newly created public schools. ${ }^{8}$ Following the recommendations of Nicholas Flood Davin, who was appointed in 1879 to investigate American industrial schools, ${ }^{9}$ the Dominion Government 
began to favour residential schools for eight- to fourteen-year olds and industrial schools for students aged fourteen to eighteen. ${ }^{10}$ Although the Canadian government continued to fund day schools from which children returned home to their families daily, authorities clearly preferred boarding schools where the child could be "disassociated from the prejudicial influence ... on the reserve of his band." 11

However, the Dominion Government never fully realized its goal of completely segregated Indian schooling. According to Inspector A.E. McGraw's 1914 Annual Report, no industrial schools were established in the Okanagan region, and the local public school teacher, Miss A.M. Easton taught up to twelve Indian students whose "behaviour and aptitude to learn" were impressive. ${ }^{12}$ Miss Nettie Walker, at Hedley public school, taught nine Indian children ranging in age from ten to seventeen, whose "writing and drawing books showed marked aptitude." 13 The following year, Indian Agent J.R. Brown confirmed these students' continued good progress and also noted that Miss K. Lawrence of Larkin School taught two promising Indian students while Miss Minnie Smith of Wood Lake School reported her five Indian students to be achieving well. ${ }^{14}$ Indian Affairs expenditures for 1915 indicate that the Dominion Government paid the province $\$ 165.34$ in total tuition fees for educating on-reserve Aboriginal students in public schools. By 1920 however, more residential and day schools had been constructed and with only approximately fifty on-reserve pupils attending public schools, the federal tuition payment consequently declined to $\$ 145.42 .{ }^{15}$ Legislation making schooling mandatory in 1920 led to increased student enrolment and an almost five-fold increase in federal tuition fees by 1925 to $\$ 738.40 .^{16}$

During the early decades of the twentieth century, the decision to integrate or segregate Aboriginal children was dependent on various factors. Availability of segregated facilities was one consideration. Discriminatory sentiments of local residents was another. In 1928, for example, lower Vancouver Island's Saanich School Board voted to exclude Aboriginal children from the local public school, citing overcrowding and poor academic achievement. Education Minister Joshua Hinchliffe supported the vote, arguing that the education of on-reserve Aboriginal children fell under Dominion Government jurisdiction. ${ }^{17}$

Economic factors also played an important role in integration matters. By the mid-1930s, integrated schooling had become a more pressing policy issue due to the Depression that was crippling the Canadian economy. In 1933, the number of Aboriginal children attending public schools Canada wide jumped to 230 as the federal government reduced expenditures for residential and day schools. ${ }^{18}$ That year, BC's Education Minister negotiated with Canada's Minister of Indian Affairs for a flat tuition fee of $\$ 20$ per annum for the public schooling of on-reserve children. Federal tuition payments to $\mathrm{BC}$ totaled $\$ 1,308.63$ in $1933,{ }^{19}$ climbing to $\$ 1,747.19$ in $1934-35 .{ }^{20}$ With increased Aboriginal enrolment in public schools, provincial normal school staff mounted a summer school "Course for Teachers in Rural and Indian Schools," the purpose being to provide practicing teachers with the "latest approved methods in rural teaching and administration" and with "a definite technique in teaching non-English-speaking children." ${ }^{21}$ 
By the end of World War II, politicians and the public alike had begun to support the idea of integrated education for Aboriginal children, due in large part to the "equality revolution" that was taking root throughout the western world to afford previously marginalized peoples equality of treatment, opportunity, and access. $^{22}$ Many Aboriginal and non-Aboriginal people voiced strong criticisms of the inadequacies of the federally-funded Indian education system during the 1946-48 Special Joint Committee of the Senate and House of Commons, ${ }^{23}$ arguing that the biggest barrier to Aboriginal children's successful transition to secondary education was the residential schools' "half-day" system..$^{24}$ The half-day system meant that students spent half their day involved in academic pursuits, with the remainder spent on work-related skill development - such as cooking and carpentry - that assisted with the operation of the school itself. In some cases, the entire "student body was out of class for long periods at critical times such as harvest." ${ }^{25}$ Testifying before the Committee in 1946, Major D.L. McKay, BC's Indian Commissioner, noted that the province enrolled "201 Indian children in white public schools" and that, generally speaking, school boards were amenable to having Aboriginal children attend their schools, although in some cases there were difficulties.

In 1947, as the Committee's hearings proceeded in Ottawa, BC's first "large-scale" integration initiative occurred with little notice when Port Essington Indian Day School was officially closed and its seventeen Aboriginal children were integrated into the local public elementary school at a cost to federal authorities of $\$ 65$ yearly per child. ${ }^{26}$ The following year, Education Minister William T. Straith was reportedly disturbed to learn that both provincial and federal schools in Hazelton were slated for reconstruction and he traveled to Ottawa to express his dismay to Hugh Keenleyside who, as Deputy Minister of Mines and Resources, was responsible for Indian Affairs. Arguing that segregated schooling was inefficient given the two schools' close proximity, Straith won Keenleyside's support to subsidize the construction of one new integrated public school. ${ }^{27}$ In 1949, Ashcroft integrated its schools, as did Telegraph Creek, Campbell River, Prince Rupert and Terrac in 1950. ${ }^{28}$

Joint federal-provincial funding for the construction and renovation of schools was certainly a driving force behind integration due to a number of factors. During the Depression and World War II, BC's public schools had suffered considerably from lack of financial and human resources. ${ }^{29}$ In 1944, the provincial government had appointed Maxwell Cameron as the sole Commissioner "to inquire into the existing distribution of powers and responsibilities between the Provincial Government and the school districts and to appraise the present fiscal position of the school districts" ${ }^{\prime 30}$ Among his many recommendations, Cameron suggested reducing the province's 828 school boards into a smaller, less costly number of units to be supported by larger local tax bases. ${ }^{31}$ Likewise concerned about money, Provincial Superintendent F.T. Fairey noted in his 1948-49 annual report that "in the interests of economy" it was desirable to "arrange for co-operation between local Boards of School Trustees and the Indian Affairs Branch for the construction and operation of schools where both Indian and white children could attend the same school." ${ }^{32}$ That year, BC amended the School Act to allow school boards and the province to enter into cost-sharing 


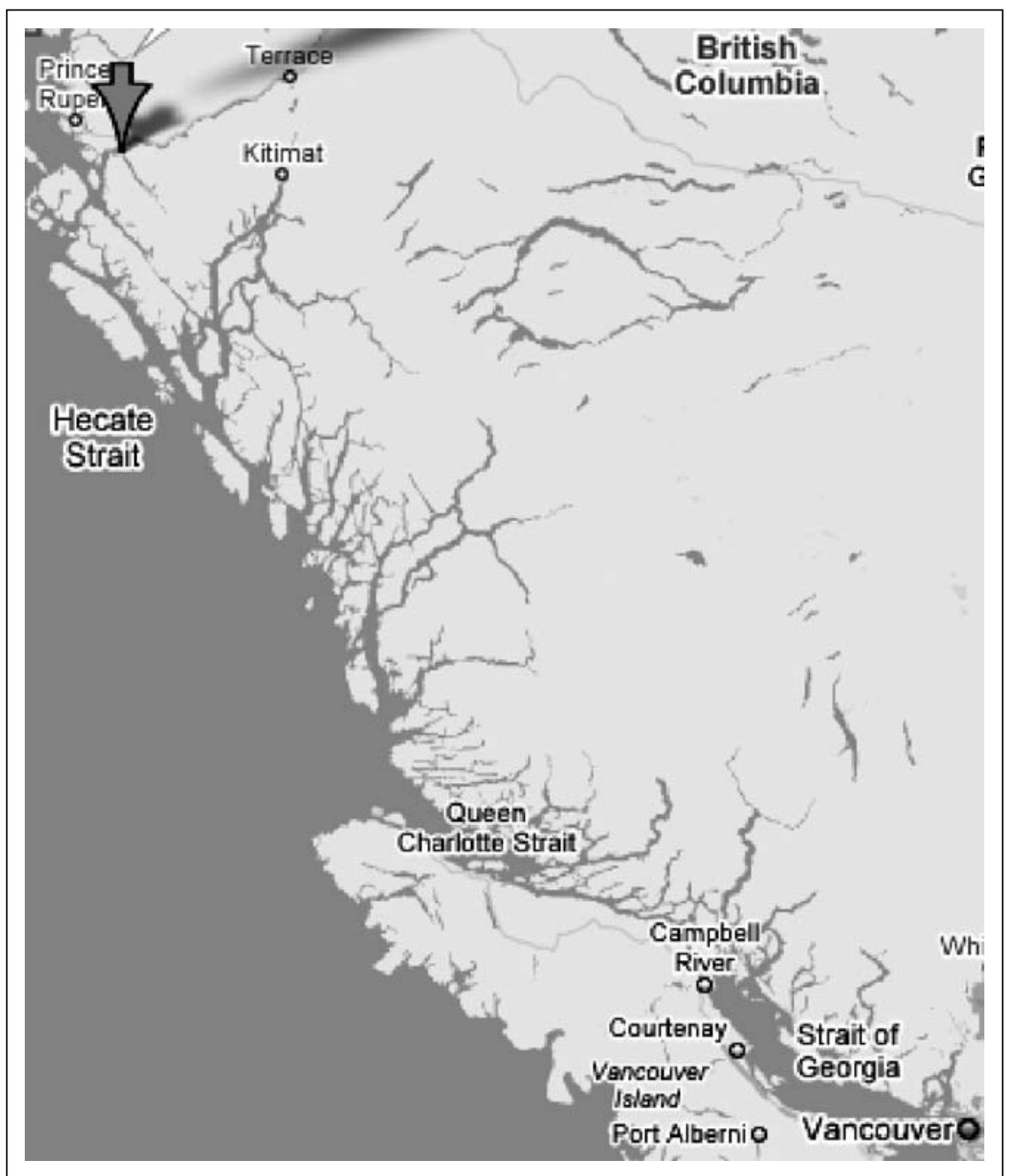

Figure 1: Arrow indicates location of Port Essington, now abandoned.

agreements with Indian Affairs for both tuition and capital costs for educating Aboriginal children. ${ }^{33}$ Capital costs were shared by the federal and provincial governments "pro rata according to the number of pupils in each category." 34

Financial factors were not everything, however. Even before the war, both Aboriginal and non-Aboriginal citizens and organizations had petitioned provincial and federal policy-makers for the improved treatment of Aboriginal peoples, and with the establishment of the Joint Committee in 1946, the abysmal living conditions of Aboriginal peoples was receiving abundant press coverage. ${ }^{35}$ Canada had been a signatory of the 1948 Universal Declaration of Human Rights and post-war developments led the province, in 1949, to extend the franchise to citizens of Indian 
and Japanese heritage. In 1950, under the Indian Inquiry Act, the province set up an Indian Inquiry Committee to investigate and make recommendations to improve the overall welfare of BC's Indians. When Doug Wilkinson, the publisher of Indian Time newsmagazine wrote to BC's Attorney General Gordon Wismer, inquiring as to what the franchise meant for Indians, Wismer forwarded the query to the Committee's chairman T.R. Kelly, who responded that the province had "accepted the native Indians of British Columbia as citizens in every sense of the word, and demonstrated the sincerity of intention of all branches of provincial administration." 36

Provincial education officials' main goal at the time was parity of educational opportunity to be achieved by increasing Indian enrolment in BC's public schools. By 1950, approximately 896 of the province's Aboriginal children were enrolled in public school $s^{37}$ and by 1951 this figure had risen to $1,000 .{ }^{38}$ Public school enrolment was greatly facilitated by federal funding and in 1949 Indian Affairs agreed to increase tuition fees for on-reserve children attending public schools to $\$ 100$ per annum. ${ }^{39}$ This sum increased a year later to $\$ 150 .{ }^{40}$

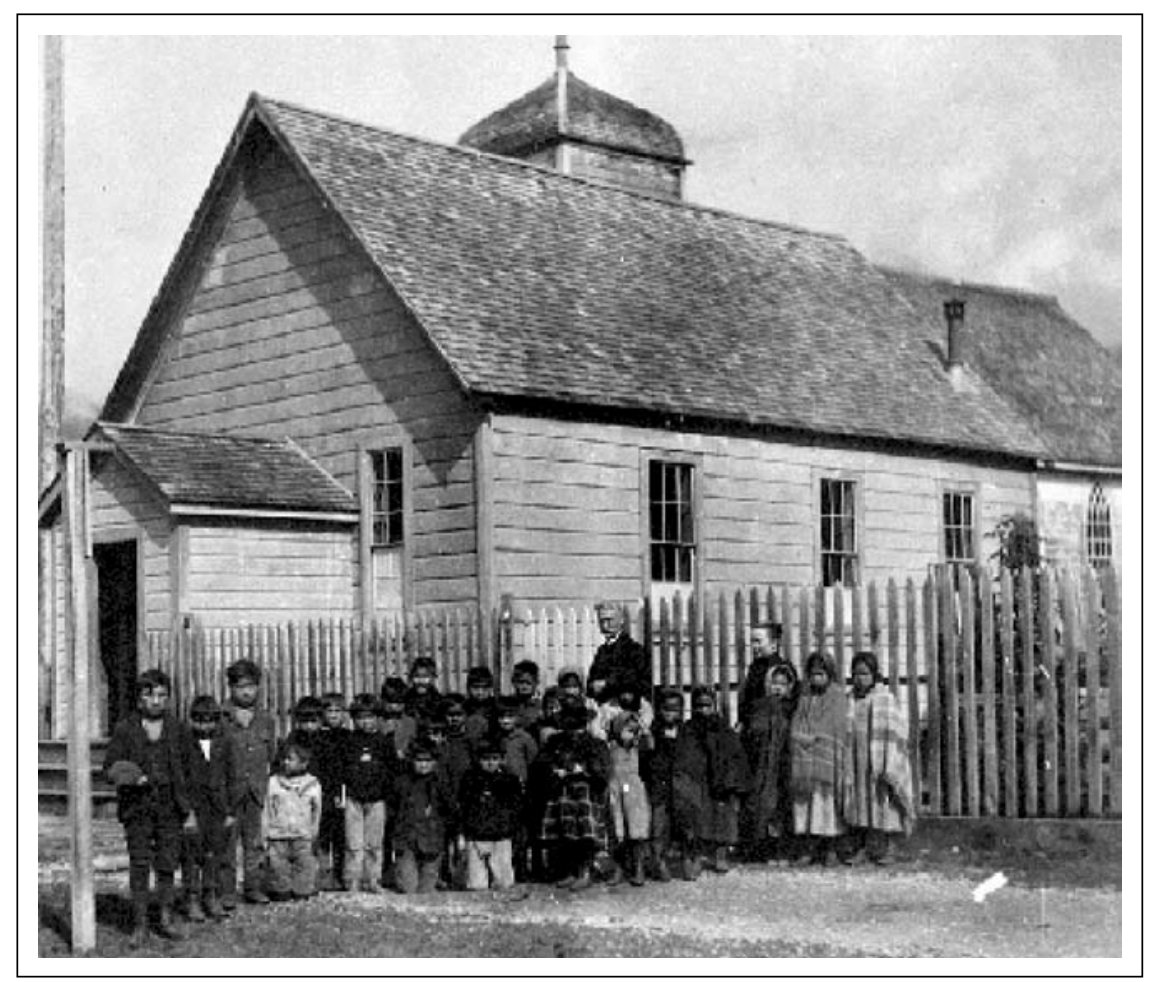

Figure 2: Port Essington Day School. Courtesy of BC Archives Collection B-05843.

In 1950, the federal Indian Affairs Branch was transferred out of the Department of Mines and Resources where it had resided since 1935 and was moved to the Department of Citizenship and Immigration. This structural change reflected a shifting federal 
policy focus away from segregation toward integration, which, it was believed, would prepare Aboriginal peoples for full Canadian citizenship ${ }^{41}$. When this was followed in 1951 by changes to the Indian Act enabling the minister to enter agreements for the provision of Aboriginal schooling with local boards, provinces, territories, and independent organizations, Canada's integration policy achieved legal status.

Provincial governments were generally supportive of the federal government's policy shift. In BC, education officials sought to facilitate Aboriginal students' transition to integrated schools by asking the Provincial Archivist, A.R. Flucke, to prepare an informational series, Indian Life in B.C., which was published between 1950 and 1952 in the $B C$ Teacher, the official organ of the British Columbia Teachers' Federation. ${ }^{42}$ In 1952, the education department offered a summer course for practicing teachers in "Indian Education" 43 and by 1955, the number of students attending provincial schools rose to 1,860 . In 1956, the province's school inspectors officially assumed responsibility for inspecting Indian day schools on behalf of the federal government. ${ }^{44}$

The task of seeking local school boards' support for integration fell to R.F. Davey, Superintendent of Education for Indian Affairs. He was assisted considerably by BC's public school inspectors who, on several occasions, notably during the Depression and World War II, had freely offered their inspectorial services when Indian Affairs lacked sufficient human resources. ${ }^{45}$ Davey and the inspectors reported that there was "little or no adjustment problem," 46 but noted the main reason for refusing to enroll Indian children was usually lack of space. In a 1950 speech to the provincial legislative assembly, Education Minister Straith stated that "as far as his Department was concerned, there would be no distinction between the education of Indian and white children in provincial schools." ${ }^{47}$

\section{Rising Discontent}

By 1958, 2,516 (or 29\%) of the province's 8,622 school-aged Aboriginal children were attending provincial or private schools with the remainder enrolled in residential or on-reserve day schools. ${ }^{48}$ By 1959 , federal authorities had signed fiftyseven agreements across the country for the construction of joint Aboriginal-White schools, twenty-two of which were in $\mathrm{BC} .{ }^{49}$ However, provincial authorities soon learned that growing enrolment did not necessarily ensure equality of educational outcomes. Since the first integration experiments, researchers across the country had been monitoring Aboriginal achievement and school completion rates. ${ }^{50}$ This research was greatly stimulated in 1949 when the Indian Affairs Branch established a research committee consisting of senior social scientists from universities around the country. ${ }^{51}$ Newspaper headlines soon proclaimed that "Elusive Indian Pupils Battle White Teachers" and that "More Attend Schools But None Ever Excel." By 1958, BC Aboriginal children's truancy and drop-out rates were being reported as high at fifty-five percent and their achievement rates very low. "They start well” reported one principal, "but there seems to be a fadeout at age sixteen or seventeen, when they get big and strong enough to work." 52 Though some researchers argued strongly that standardized IQ tests were culturally and linguistically biased against Aboriginal 
children, leading to artificially depressed scores, the arguments of pro-test researchers won the day. ${ }^{53}$

Educators and administrators within the system attributed failure to the children and their families:

Indians had no tradition of continued hard work, or long-range planning. Indians were hunters, fishermen, harvesters of roots and berries. They worked hard by fits and starts in the season, laid up a winter's food supply, then enjoyed themselves with dancing, feasting, gambling and social ritual. They worked cooperatively. They had no clocks. In the more remote parts of $\mathrm{BC}$ some parents spirit their children away to the woods rather than let them go to school ... many Indian householders are indifferent to schooling and some of those who are enthusiastic for education in theory make no attempt in practice to provide an atmosphere for study or urge their children on to greater effort. ${ }^{54}$

Some educators and administrators supported this argument by noting the large variability in Aboriginal student achievement in different regions of the province. ${ }^{55}$

In 1959, Leslie Peterson, a UBC graduate student, explored various aspects of Indian education in the province and suggested, in addition to other findings, that low Aboriginal school completion rates were due in part to segregation and discrimination that endured in the larger society in spite of integrated schools. He cited numerous situations in which Aboriginal students had completed high school but failed to find employment afterward and opted to return to their reserves where unemployment was high. Peterson summed up by saying that "the Indians of British Columbia are by no means all convinced that White education is beneficial." 56

Others opted for different explanations for Aboriginal children's poor results and-supported by a growing body of social science research - put the blame squarely on the public schools. Some argued that unlike other Canadians, Aboriginal children were raised in families where non-verbal communication was more highly valued than verbal. They claimed that mainstream teachers both talked a great deal and encouraged verbosity in their students. As well, Aboriginal children, it was charged, were not raised to compete with one another, but rather came from cooperative social structures. Corporal punishment had not traditionally been an acceptable form of discipline for Aboriginal people, and yet it was an integral part of public school management. The curriculum was criticized for not reflecting the reality of these children, as were the biases of White teachers, the scarcity of Aboriginal teachers and the lack of Aboriginal representation on local school boards. ${ }^{57}$

The most influential of social science research was the 1958 publication The Indians of British Columbia, by UBC anthropologist Harry Hawthorn and his colleagues Cyril Belshaw and Stuart Jamieson. Hawthorn's report drew attention to the high rate of age-grade retardation and drop-out among Aboriginal children. Teachers who spoke with Hawthorn and his team "reported knowledge of 360 children who had left school within the previous three years," 58 six of whom had left as early as Grade One. By far the largest group had dropped out in Grade Eight. Two-thirds of 
the teachers the researchers surveyed painted bleak pictures of Aboriginal children, emphasizing failure. The authors also noted that Indian children's home environments clashed with those of the general student population, particularly with respect to the use of non-standard English, different concepts of time, and different social relationships. They argued that cultural "deficits" rendered Aboriginal children "unprepared" for school "where the content of new learning must perforce be greater than for a White child of comparable maturity." 59

The Hawthorn report was hailed by many as the key to understanding low- achieving Aboriginal children. Hawthorn's report noted briefly that many Aboriginal students attended school irregularly due to their families' employment in fishing, fruit-picking and other seasonal activities. However, no attendance statistics were provided and the matter was brushed aside in favour of a more anthropological line of argument. Though no systematic analysis of student achievement was undertaken, Hawthorn et al recommended that teachers working with Indians acquire better knowledge of elementary linguistics, anthropology, sociology and psychology; awareness of issues in contemporary Indian life; and understanding of the school's community. Commissioned by the federal government, Hawthorn's report received prominent coverage in the press and the discourse surrounding Aboriginal schooling began to emphasize the clashing world views of Aboriginal and non-Aboriginal learners. This occurred despite the fact that achievement figures were never probed, nor were factors that possibly contributed to student drop-out, such as poverty and poor attendance rates. ${ }^{60}$

In spite of Hawthorn's criticisms, across the country integration initiatives accelerated, largely in the form of federal-provincial construction of new integrated public schools. In British Columbia, the 1963-64 school year witnessed the enrollment of 4,021 Aboriginal children in integrated public schools. ${ }^{61}$ In the case of some remote areas without high schools, students would board in large cities to attend school. In such situations, the home district usually reimbursed the recipient district, although Vancouver was known to waive its fee. ${ }^{62}$

As overall educational costs grew exponentially during the 1950s and 1960s, funding became more of a concern for provincial authorities. In 1963, Indian Affairs agreed to revise its tuition fee - an event officially marked by way of provincial order-in-council. Although the new $\$ 250$ per year fee ${ }^{63}$ signaled a substantial increase over the $\$ 150$ negotiated in 1950 , some people considered the amount inadequate. In a report to Indian Affairs, D.B. Fields, a UBC Accounting Professor, and W.T. Stanbury, a UC Berkeley PhD student, used Department of Education figures to argue that $\$ 250$ represented only $56.2 \%$ of the total cost of educating on-reserve Aboriginal students in public schools. They suggested that the provincial government was actually subsidizing Indian education by approximately $\$ 223$ per student annually. ${ }^{64}$

\section{Broadening Provincial Responsibilities}

Provincial discontent over federal funding was but one manifestation of the acrimony growing between the two levels of government by the mid-1960s. In a 1965 radio 
broadcast, Provincial Secretary and Minister of Social Welfare Wesley Black announced that during World War II provincial governments had withdrawn "from a number of taxing fields for the avowed purpose of making as easy as possible the conduct of the war by the Federal authorities." ${ }^{65}$ Black argued that as a consequence, high levels of revenue were finding their way into federal coffers while the provinces struggled to maintain their mandated social services. The time had come, he argued, to redress this imbalance and to hold Ottawa accountable for the moneys it collected. ${ }^{66}$ Black's views had been greatly influenced a year earlier at the Federal-Provincial Conference on Indian Affairs where the federal government announced its desire for the provinces to participate more actively in the administration of Indian affairs. At the conference, Black noted that $\mathrm{BC}$ was favourable to the idea of Aboriginal peoples receiving government services comparable to other citizens, particularly in health, education, and welfare, but that these services were contingent upon adequate federal funding. ${ }^{67}$

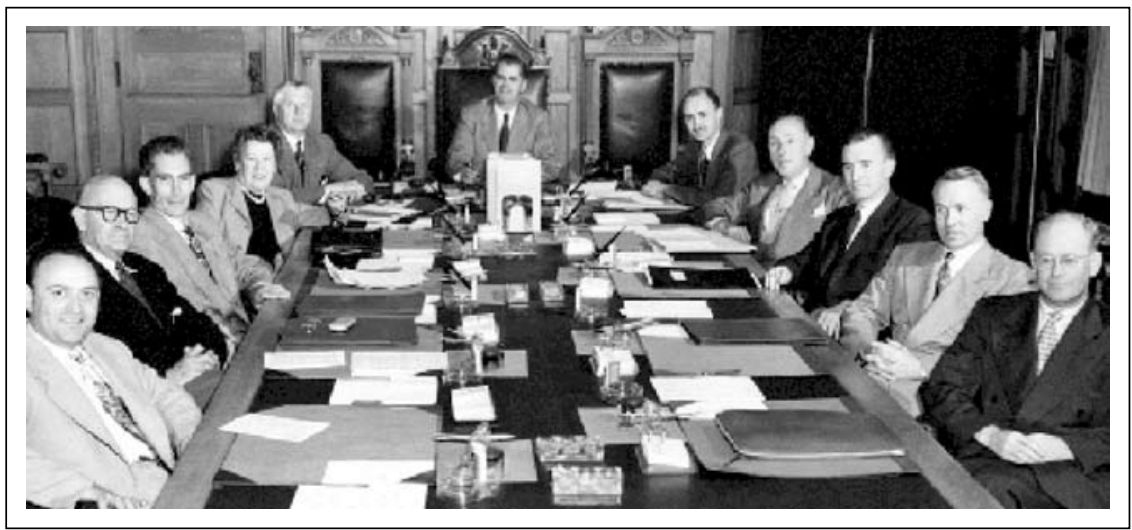

Figure 3: BC Cabinet of W.A.C. Bennett, Wesley Black is fourth counting from the far right. Courtesy of BC Archives Collection, B-06613.

In 1967, Harry Hawthorn produced a second report that further elaborated differences between middle-class Whites and natives. ${ }^{68}$ Aboriginal life expectancy was lower than for Whites while infant mortality and suicide rates were higher. National per capita income was five times that of Aboriginal peoples. The report also blamed Indian children's failure in school on disparities in housing, clothing, food, playthings, learning styles, use of language, methods of discipline and opportunities for making decisions. As in the earlier report, Hawthorn advised that the school system should change: that teachers be better trained, that better programs be designed, that Indians receive language instruction in one of Canada's official languages, that materials reflect Aboriginal lives and contributions to Canada and that Aboriginal parents become more involved. According to Hawthorn, "educational programs should take into account the obvious differences in background of the Indian student and also the often less obvious differences in values and motivations." ${ }^{69}$ Changing post-war sentiments emphasizing the importance of social and political parity for previously marginalized 
groups ensured that Hawthorn's recommendations were well received.

By the latter half of the 1960s, the list of dilemmas plaguing Aboriginal schooling were increasingly laid at the feet of senior civil servants in the provincial Department of Education. In 1967, the Indian Affairs Branch wished to cease negotiating school agreements with individual school boards and insisted that the provinces be responsible for administering the public schooling of on-reserve children. ${ }^{70}$ The federal government pressed strongly for provincial administration of social services for Aboriginal peoples, arguing that this move would alleviate Indigenous peoples' problems by hastening their development as full citizens, entitled to the same rights and services as other Canadians. ${ }^{71}$ Testifying before the 1968-69 Standing Committee on Indian and Northern Affairs, R.F. Davey, Director of Indian Education, emphasized that the "amount of paperwork" necessary for monitoring all the school board agreements was "fantastic." 72 Others informed the committee that there was much confusion surrounding Indian Affairs policies due to the number of boards and councils involved. ${ }^{73}$

The federal government's first step in ridding itself of its dealings with local school boards occurred in February 1969 when R. Battle, Assistant Deputy Minister of Indian Affairs, and Neil Perry, Deputy Minister of Education, signed the first "Master Tuition Agreement" (MTA) which was retroactive to July 1, 1968. This agreement, which repealed all prior agreements signed between Indian Affairs and local districts, assured that all Aboriginal children were eligible to enroll in public schools in all districts in which their reserves were located under the same terms and conditions as non-Aboriginal children. The federal government agreed to pay a flat tuition fee of $\$ 533$ per child per year as well as capital expenses calculated as a ratio of the number of Aboriginal children to the total number of children. ${ }^{74}$ Provincial officials accepted the new agreement willingly, partly because it represented a new source of muchneeded funding, and partly because they preferred to deal directly with Ottawa over Indian education rather than indirectly through local districts. ${ }^{75}$

In 1968, BC Premier W.A.C. Bennett established the First Citizens' Fund, which, among other things, allotted \$25 million for generating \$1.2 million for scholarships for Aboriginal students. ${ }^{76}$ In that same year, a new category was added to the list of Special Education programs funded by the Department of Education. "Indian Orientation" was funded through an approval process that had previously been restricted to students who had physical or mental impairments, or who were not English speakers. One pilot orientation program was approved, enrolling sixteen students in 1968 , and a year later, a second was approved, increasing the number of funded children to twenty-three. ${ }^{77}$ This program resulted from various factors that coalesced at the end of the 1960s, the first of which was pressure from the federal government. Specialized Indian programs were strongly encouraged by federal Indian Affairs officials who had already begun such initiatives nation-wide in residential and day schools. Under the direction of Reverend Ahab Spence, of Aboriginal ancestry himself, the Indian Affairs Education Branch supported language instruction as well as cultural orientation. Textbook revision was under way and branch officials negotiated with the provinces to purge public school curricula and texts of negative images and stereotypes. ${ }^{78}$ 
Structural changes within government also contributed to the new program offerings. By the early 1970s, the Department of Education was revising its system for providing services to special needs learners. Until that time, government policy greatly restricted districts' special service provision. Districts were only permitted to offer special instructional services to three percent of their total student population. Furthermore, such services could only be offered within an intact class within a specified school building. For many districts this proved problematic due to higher (or lower) than average numbers of special needs learners, and to students who were hospitalized for prolonged periods due to illness. Superintendent of Special Services Les Canty and Superintendent of Finance Ed Espley brought this dilemma to Minister of Education Donald Brothers who assigned them to devise a new allocation system. In 1971, Canty announced a new system for approving special services, which allowed for the hiring of special instructional assistants to be funded on an "as-needed" basis. ${ }^{79}$

In 1970, The First Citizens' Fund Committee appointed a special consultant to the Department of Education "to work on curriculum and instructional problems related to the education of Indian children in public schools." ${ }^{80}$ The department also began preparing teaching materials for use with Aboriginal students and made changes to selected textbooks and curricula to reflect better the reality of Aboriginal children. The department published a book series entitled "Our Native Peoples" in order that all public school children develop an appreciation of Aboriginal heritage. ${ }^{81}$ That year, three-quarters of BC's 13,000 Aboriginal pupils were attending public schools, with 38,837 enrolled across the country. ${ }^{82}$

Despite these initiatives, the press continued to castigate schools for failing Aboriginal learners. From 1966, when Hawthorn published the first volume of his second report, to 1973, over thirty articles appeared in the province's four largest daily newspapers (The Vancouver Sun, The Province, The Times and The Colonist) lamenting the deplorable state of Indian education. It was reported, for example, that in reading students were "two or three years below the average grade levels." ${ }^{33}$ Many writers offered quick solutions and most proposed changes to the system in the form of programs to teach Indians to "take pride in their accomplishments" and to teach racial tolerance to non-Indians. Some blamed the failure of Aboriginal children on teachers who were "ignorant of Indian students' backgrounds." Others blamed the curriculum. Many parents and critics alike continued to request greater Aboriginal parent involvement in educational decision-making, while at the same time expressing frustration at the foreign environment that Aboriginal children faced in most classrooms. ${ }^{84}$ Still others accused Aboriginal parents of not wanting their children to be educated since they themselves were uneducated. Finally, a few saw the situation as insoluble, arguing that the Aboriginal child faced two conflicting pressures: "one to ignore non-Indian society, the other to accept it," resulting in an impossible learning situation. ${ }^{85}$

BC's Department of Education officials addressed these criticisms by increasing funding for specialized Aboriginal programs. In 1970, the Department funded the Greater Victoria School District for three full-time counselors and one stenographer 
to assist Aboriginal learners to enroll in adult training classes. ${ }^{86}$ The following year, Victoria's Craigflower Elementary School in Victoria hired tutors from the Songhees reserve to teach approximately twenty-five children their native history, myths and crafts. Other provincially-funded initiatives included consultation with Aboriginal groups regarding the improvement of curricula and textbooks and in-service preparation for teachers of Aboriginal students. Indian Studies programs and Indian Resource Centres were established at various community colleges and universities in order to address the needs of Aboriginal students who, it was argued, learned best informally, in groups, and more co-operatively than non-Aboriginal learners. ${ }^{87}$ Between 1973 and 1974 , BC spent over $\$ 1.2$ million to hire special teachers, teacher-aides and home-school coordinators for Aboriginal children in the public system. ${ }^{88}$

During this time, much of the discussion over Aboriginal schooling was conflicted. In 1971, Frank Calder, a Nisga'a MLA, admonished Education Minister Donald Brothers in the legislature for proposing special treatment for Aboriginal children. Calder himself had attended an integrated public school and university and felt Aboriginal students could compete on equal footing with non-Aboriginal children. ${ }^{89}$ Addressing the Legislative Assembly in 1973 as a newly-appointed cabinet minister, Calder had softened his views, and supported the notion of schools preserving Aboriginal cultural identity. He believed that by sanctioning the teaching of Aboriginal

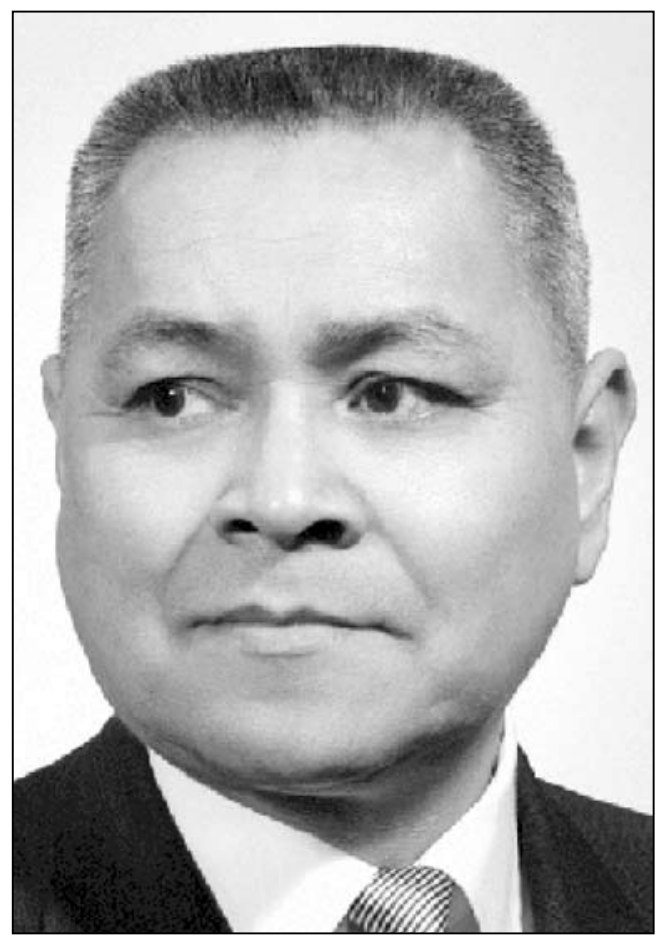

Figure 4: BC MLA Frank Calder. Courtesy of BC Archives Collection, I-32431. languages, the Department of Education "would go a long way towards re-establishing a sense of pride in Aboriginal ancestry and the resulting feeling of dignity and self-worth which were an inherent part of Aboriginal people before the arrival of he European." 90

Missing from the discourse of the time were investigations into links between drop-out (cited at ninety-four percent in 1970) ${ }^{91}$ and non-school-related factors, such as discrimination in hiring policies, lack of employment opportunities, poor living facilities, and extreme poverty linked to the economic circumstances of individual reserves. The reality was that a graduation certificate did not always promise a better life for many Aboriginal children, particularly if they chose to stay close to their families on 
reserves where unemployment was high and economic opportunities low, due to the paternalistic system of governance that had developed in Canada through the reserve system.

Though concern for the welfare of Aboriginal peoples had grown appreciably across the country, there was a dearth of provincially-based "hard data available to policy-makers about the social and economic characteristics of native people," ing provincial policy-makers to rely often on a vast and growing body of research undertaken elsewhere in North America. Further complicating matters was the fact that every expert seemingly held a different answer to the "Indian problem." Anthropologists such as Hawthorn and his team pointed to differing socialization and social orientations of Indian students versus non-White students. ${ }^{93}$ Linguists, on the other hand, claimed the source of difficulty was linguistic and advocated teaching Aboriginal students English as a second language through bilingual education programs. ${ }^{94}$ Social psychologists argued that poor self-concept was responsible for Aboriginal children's academic failure. In most cases, however, scholars' pronouncements revealed their own middle-class orientations and their own conceptions of the reality of the "average" White child — if indeed such a child ever existed. One critic, writing in 1973, surely had no idea how many — if not most — of Canada's children lived when he claimed that the Indian child is at a disadvantage for he cannot function in the "white child's world of color TV, trips to the ski slopes, ballet lessons, library books and weekends at the summer cottage." 95

In 1968, the Educational Research Institute of BC began supporting research projects to study Aboriginal schooling. While many projects were co-funded with the Department of Education, most reflected research findings from elsewhere in North America. In 1968, for example, three University of Victoria professors received funds to operate summer orientation, pre-school and pre-kindergarten classes for Aboriginal children fashioned on the American "head-start" programs. Citing the "cumulative deficit hypothesis," the professors claimed that Aboriginal children lacked self-confidence and stimulus in the home, while suffering from undernourishment and impoverished language skills. Over a period of one month, the organizers sought to ameliorate these deficiencies and better prepare the participants for schoolbased learning. Although students' fine and gross motor skills improved, the program did not succeed in improving students' language competencies. ${ }^{96}$ Other sponsored projects sought to understand student interaction patterns in integrated schools; to develop science and mathematics programs targeted at Aboriginal secondary students; to compile sourcebooks for Aboriginal languages, writing systems, legends, and stories; and to teach traditional Aboriginal skills and crafts. Amid the academic inquiry, Aboriginal groups across the country increasingly demanded control of their children's schooling.

A key event which helped to accelerate Aboriginal demands for educational selfgovernance occurred in June 1969, when Jean Chrétien, federal Minister of Indian Affairs and Northern Development, tabled before the House of Commons A Statement of the Government of Canada on Indian Policy — commonly referred to as the "White Paper." In it, the Liberal government promised to work towards equalizing native 
rights by eliminating special status and providing only those services enjoyed by the rest of Canadians. ${ }^{97}$ The paper proposed that the Indian Act be repealed, that the Department of Indian Affairs be dismantled, that the provinces assume responsibility for Indians and that the control of reserves fall directly into the hands of their occupants. ${ }^{98}$

Aboriginal groups across the country opposed the paper, first and foremost, for its lack of supposed "consultation" which the federal government had promised prior to the White Paper's publication. ${ }^{99}$ They also disagreed with the provinces assuming responsibility for them as this would require Aboriginal groups to negotiate with more than ten governments, as opposed to one. They rejected the idea of Indian control of Indian lands lest private ownership result in private sales and eventually lead to the dissolution of their culture. ${ }^{100}$ Within six months, Harold Cardinal, a Cree lawyer and President of the Indian Association of Alberta published his book The Unjust Society, a scathing attack on the White Paper which he believed to be one more manifestation of Canada's assimilationist policies. Cardinal was particularly critical of residential schooling, stating that "the child went to school an Indian. The young man emerged a nothing." 101

Starting in June 1970, Aboriginal organizations across the country responded to the White Paper by presenting a series of position papers to the federal government. Quoting from the Hawthorn reports, the Indian Chiefs of Alberta (ICA) argued that Indians should be regarded as "Citizens Plus," possessing the rights and duties of Canadians, but eligible for additional rights as one of the nation's founding members. The ICA recommended - among other things — direct payment of federal education funds to tribal councils and revision of existing curricula to include native content. ${ }^{102}$ In 1971, the Manitoba Indian Brotherhood followed up the ICA's critique by publishing Wabbung Our Tomorrows which argued that education was essential to improving social and economic conditions for Aboriginal peoples. It further stressed that education is an holistic undertaking, including not only the school, but the "social, cultural and economic fabric of communities:"

The history of education up to the present day reflects a definition of education in terms of schooling... In developing new methods of response and community involvement it is imperative that we, both Indians and Government, recognize that economic, social and educational development are synonymous and thus must be dealt with as a total approach rather than in parts. ${ }^{103}$

The report also called for greater parental involvement in the education of their children.

In December 1972, the National Indian Brotherhood (NIB) - later the Assembly of First Nations - presented its historic policy statement, Indian Control of Indian Education to the Minister of Indian Affairs. This document, consisting of papers and reports from a workshop held in June 1972, signaled a turning point in the discussions by calling for the transfer of educational control directly to Aboriginal parents. ${ }^{104}$ 
Integration in the past twenty years has simply meant the closing down of Indian schools and transferring Indian students to schools away from their Reserves, often against the wishes of the Indian parents.... Indian children will continue to be strangers in Canadian classrooms until the curriculum recognizes Indian customs and values, Indian languages, and the contributions which the Indian people have made to Canadian history.... We must, therefore, reclaim our right to direct the education of our children. ${ }^{105}$

The statement also called for band council involvement in negotiating all future federal-provincial agreements, the transfer of federal funds directly to band councils (not to the provinces), representation on school boards, the appointment of Aboriginal peoples to curriculum development staffs, removal of biased textbooks, elimination of IQ and standardized tests, the infusion of Aboriginal content into curricula and improved training for teachers and counselors working with Aboriginal children. The federal government quickly retracted the White Paper and officially endorsed the NIB's policy paper. ${ }^{106}$

\section{Sharing Control}

Indian Control of Indian Education had a profound impact on officials in BC's Department of Education. ${ }^{107}$ After the provincial election in August 1972, Eileen Dailly, a former school trustee, became Education Minister. Dailly concurred with the critics of education and stated that the system was outmoded, needing to become more responsive to its students' needs. In her 1975 address to the annual BC Teachers' Federation conference, she vowed not to "swing back the pendulum." Dailly declared that teachers, administrators and government were "in the centre of the struggle for control of public education" and were "faced with the dilemma of maintaining a common public school system in a diverse, pluralistic society." ${ }^{108}$ The Minister and her advisors were supportive of Indian-controlled schooling and opposed both residential and integrated schooling. ${ }^{109}$ Assuring Aboriginal people that no decisions would be made without their input, Dailly appointed George Wilson, an Aboriginal teacher, to the Department of Education's newly-created position of Director of Indian Education in 1972. ${ }^{110}$

Dailly's administration greatly accelerated provincial initiatives in Aboriginal schooling, often prompted by developments in other parts of the country. In September 1973 the Supreme Court of the Northwest Territories ruled that Indians had Aboriginal rights to the western section of the Territories and could therefore propose a land claim. This landmark ruling helped to mobilize indigenous groups across the country. That same year, Dailly announced that by 1975 , the Nisgaa people of $\mathrm{BC}$ would be granted their own, native-controlled school district, following a Supreme Court stalemate over Nisga'a land claims. ${ }^{11}$ A split ruling over the case "tossed the ball into the politicians' court" and led Prime Minister Pierre Trudeau to state that perhaps natives had more legal rights than he had earlier believed. ${ }^{112}$

Under Dailly's tenure, supplementary (non-base) funding for Aboriginal education 
increased almost six-fold from $\$ 131,000$ in $1971-72$ to $\$ 742,000$ in $1974 .^{113}$. In 1974 , the Minister instructed the Education Department to strike a Minister's Committee on Indian Education, which included representatives from the Department, the Union of Indian Chiefs, the BC Native Indian Teachers Association, the BC School Trustees Association, and the Children's Aid Society in Vancouver, ${ }^{114}$ with a budget of $\$ 82,000$ for the year of which $\$ 32,000$ was allocated for a province-wide conference on working with Aboriginal children. ${ }^{115}$ In November of that year, the provincial government also granted UBC \$150,000 to begin the Native Indian Teacher Education Program that had earlier been endorsed by UBC's Education Dean in $1973 .{ }^{116}$

In 1974, Dailly introduced a policy of curriculum decentralization to the province. With this move, school districts received the green light to adapt provincial curricula and resources to meet local needs. Decentralization reflected Dailly's belief that the "primary relationship in education is between the teacher, the pupil and the parent" 117 and although Dailly argued that each student in the province should be offered a "core program," the intent of which was to ensure "the development of functional literacy," such a core was never articulated. Boards were not only permitted to design courses of study, but also, they could now authorize "textbooks, supplementary readers and other instructional materials for use in their districts." 118 The Department of Education provided financial incentives and resources to local districts to encourage local curriculum development. ${ }^{119}$

In 1975, by order-in-council, the BC government established the Nisga' School District in the Nass Valley, comprising the villages of New Aiyansh, Greenville and Kincolith. The new district's Board of Trustees consisted entirely of Aboriginal members. In their Declaration, the Nisga'a stated that "Indians should be regarded as Citizens-Plus; in addition to the normal rights and duties of citizenship, Indians possess certain rights as charter members of the Canadian Community." 120 In that same year, $\$ 22,800$ was awarded to the BC Native Indian Teachers Association to support various teacher development programs.

In addition to educational services, the province began providing school districts and Aboriginal communities with more social services in an effort to improve Aboriginal students' educational standings. In December 1976, Dr. Saul Arbess, a cultural anthropologist, succeeded Jaqueline Leo as Director of Indian Education within what was now the provincial Ministry of Education. ${ }^{121}$ Arbess implemented various initiatives under a special cost-sharing arrangement in which districts applied for funding to "top-up" base funding. ${ }^{122}$ One such program in Dawson Creek was aimed at keeping native children in school until at least grade ten, by serving children a "substantial breakfast before regular classes," thereby increasing Aboriginal children's classroom attention span. ${ }^{123}$ That year, funding for special Aboriginal programs leapt to $\$ 1,564,000 .{ }^{124}$ In 1977 , funding increased to $\$ 2,224,600$, marking a 40 percent increase in Aboriginal education funding from 1966 to 1977.

Senior Ministry of Education officials were greatly concerned about the low completion rates for Aboriginal learners, estimated at approximately 20 percent in 1976. ${ }^{125}$ Arbess's role was to fund local school initiatives in the hopes of improving Aboriginal students' educational standing. He spent much of his time traveling the 
province convincing districts to make funding requests to the province for special programming. Requests were proposed to Arbess who, in turn, recommended them for approval to the Ministry's Superintendent of Schools. In selecting which programs to fund, Arbess first judged whether the district had the human and material resources to undertake the project. He also required that districts partner with local bands to ensure the community's approval.

Although the Ministry also funded alternative programs such as a wilderness camp for secondary Aboriginal students at Jarvis Inlet near Sechelt, most funding approvals were granted for hiring district coordinators and directors who would oversee curriculum and resources. Also hired were classroom teaching assistants, cultural specialists, learning assistance teachers and home-school coordinators who worked directly with families.

In 1978 the Ministry also sponsored a conference in Vancouver entitled: "Telling Our Own Stories" which Arbess organized. Some 800 people attended, including linguists, Aboriginal community members, teachers, and cultural workers. A second conference followed in 1980, entitled "Chinook" and focused on teaching Aboriginal languages. Special Program approvals climbed to 149 in 1979 and to 162 in $1980 .{ }^{126}$ In February 1981, Arbess toured the province helping teachers learn how to optimize learning environments for Aboriginal children. In his workshops, Arbess outlined the key differences between Aboriginal and western pedagogy and helped teachers to become more culturally sensitive. Arbess also instructed teachers in the use of multimodal approaches, such as guided imagery, since sensory techniques had proven successful with Aboriginal learners, due to Aboriginal children's alleged superior visual acuity. ${ }^{127}$ A 1982 survey of the Ministry's initiatives illustrated superintendents' satisfaction with the services and relationships forged between the Department and the districts.

\section{More of the Same}

Government support for Aboriginal programming initiatives remained high throughout the 1970s, even after the left-leaning New Democratic Party lost power in 1976 to the more fiscally-oriented Social Credit Party. In January 1979, Deputy Minister Walter Hardwick outlined for the Education Minister a Policy Statement on Indian Education, which emphasized the Ministry's concern with Aboriginal underachievement and drop-out. The statement was intended to reaffirm government's "commitment to achieving parity for native Indian children in the public schools" and clarify "areas of initiative and emphasis in the provincial Indian Education program." 128 Item 3 of the Policy Statement set out the Ministry's commitment to equality "through regular and special needs education programs."129

In 1980, newly-appointed Education Minister Brian Smith toured the province "to determine what the people of this province wanted in their education system." 130 In addition to holding forty-one public forums to hear public concerns, Smith visited various schools where he observed classes and spoke with students and educators. The Minister had been particularly impressed by the Nisga'a district where 
he "watched students mastering the Nishga dialect" and when he published his report in 1981 he promised to produce "a number of curriculum documents" to help "teachers to adapt their teaching strategies to the needs of Native Indian children."

${ }^{131} \mathrm{He}$ also vowed to establish a "Provincial Curriculum Resource Centre" for sharing curricular materials tailored for Aboriginal students.

But Smith's promises seem to have fallen on deaf ears. In 1981, the Union of BC Indian Chiefs issued a policy statement calling for the "non-recognition of the public schools as an alternative for the education of Indian children," 132 and supporting "exclusively" the concept of Indian-controlled schools. In response, the Ministry of Education's Special Programs Branch decided that the "public school option must be clear and strong to counteract this separation and the withdrawal of native Indian children from the public schools." ${ }^{133}$ With this, the Ministry's policy committee allotted an additional $\$ 330,000$ for changes to curricula, program implementation, learning assessment, special programs, and services for publications, facilities, in-service training and data collection.

In 1982, the provincial economy fell into a debilitating recession and the Social Credit government announced its restraint program by placing a 12 percent ceiling on the expenditures of all provincial public bodies. The Indian Education Branch came under scrutiny at this time, given that the budget had risen from approximately $\$ 2$ million in 1976 to over \$6 million in 1982. A questionable light was further cast on the Ministry's initiatives when UBC professor Art More surveyed 300 provincial Aboriginal schooling projects and concluded that there was "almost a total lack of internal and external accountability.... Programs are never evaluated, the problems are never caught, and they never improve." ${ }^{134}$ Despite government restraint and More's critiques, the Ministry of Education continued to increase resources for Aboriginal education. In 1983, the Indian Education Branch published "Successes in Indian Education" and by 1985 had increased overall spending to almost $\$ 30$ million. Critics continued to lament Aboriginal students' lacklustre achievement.

\section{Conclusion}

What conclusions can be drawn from this narrative recounting three decades of provincial integration efforts? First and foremost, this research reveals that British Columbia's integration initiatives - legalized by changes to the provincial School Act in 1949 - were underway several years prior to the federal government's policy shift from segregation to integration, embodied by the 1951 Indian Act. Although small numbers of Aboriginal students attended public schools in British Columbia from as early as the turn of the twentieth century, more large-scale integration initiatives occurred following World War II, beginning with the closure of Port Essington day school in 1947. British Columbia's experiences with integrated schooling remind us that oftentimes, legal and policy frameworks are enacted to legitimize existing practice and not vice versa. ${ }^{135}$

Findings from this research also challenge parts of research literature which conceive of educational policy development as a "rational" process comprised of linear 
stages where school-based problems are identified; where values, goals, options and objectives are defined; and where benefits, costs, and strategies are analyzed before actions are determined and implemented. ${ }^{136}$ Indeed, British Columbia's early integration initiatives had less to do with dilemmas within the province's education system than with larger social, political and economic considerations impacting Aboriginal affairs outside of public schooling, largely due to the disastrous effects of the Canadian government's assimilationist education policy that created and sustained the ill-fated residential school system. Indeed, no officials from the BC Department of Education were involved in negotiations during the 1960s which led to the transfer of social welfare programs from federal to provincial officials. ${ }^{137}$

In perspective, early efforts at integrated schooling appear notable for their simplicity. Early initiatives consisted of little more than erecting or renovating schools into which Aboriginal and non-Aboriginal learners were installed, reflecting the belief of government officials at all levels - federal, provincial and local — that educational parity was to be achieved through equality of opportunity. These early developments were in fact nothing more than co-education and lend support to the contention that integration efforts were synonymous with the federal government's earlier assimilationist schooling agenda. ${ }^{138}$

By the late 1960s however, Canadians' more favourable post-war attitudes toward previously marginalized peoples were well entrenched and would pave the way for equality-promoting social policies such as the Official Languages Act, the Multiculturalism Policy and the replacement of federal Indian agents by on-reserve band councils who would oversee band affairs. As Canada's "equality revolution" unfolded, provincial authorities increasingly affirmed their support for achieving educational parity for Aboriginal children by adopting much broader notions of schooling to include linguistic, cultural, psychological and social services. ${ }^{139}$ As the authority of social science research prospered within Canada's new socio-political climate, educational officials accepted the view that the education system must adapt to the special linguistic, cultural and psychological needs which allegedly prevented Aboriginal children from succeeding. With this acceptance, the province's central authorities employed all of their available levers - policies, funding, curricula and resources - in an attempt to effect change in the public schools. Thus, provincial integration efforts between the late 1960s and early 1980s are more accurately characterized as integrative rather than assimilative.

But legislation, policies, curricula and resources do not necessarily lead directly to equality of educational outcomes. According to Berkhout and Wielemans, the power of the state is circumscribed by contextual, institutional features that render the policy process contradictory and discontinuous. ${ }^{140}$ As various policy researchers have reminded us, "change ultimately is a problem of the smallest unit" and depends on "the individual at the end of the line." ${ }^{141}$ This seems particularly true in the case of public schooling for Aboriginal children in British Columbia where central, provincial authorities had jurisdiction over educational governance (laws, policies, and standards) but where program administration was ultimately the job of local authorities. ${ }^{142}$ As Koenig notes, implementation is indeed "the great Achilles 
heel of the policy process." ${ }^{143}$ In 1981, the province had yet to understand what the federal government had learned long ago: that without a significant presence in the schools themselves, neither federal legislation, nor money, nor educational curricula or resources administered from a distance were sufficient for central authorities to leverage province-wide changes in the lives of individual Aboriginal learners. Another twenty-five years would pass before the province agreed to enable Aboriginal people to establish their own school districts and fully begin to implement "Indian control of Indian education." 144

\section{Notes}

An earlier version of this paper was presented at the 2006 biennial meeting of the Canadian History of Education Association at the University of Ottawa. I wish to thank Thomas Fleming, Bob Gidney, Wyn Millar, and two anonymous HSE reviewers for their helpful feedback. I also thank the Social Sciences and Humanities Research Council, for financial assistance for research assistants Peter Wolfe and Ma Xiangyu.

1 J. Barman, Y. Hébert, and D. McCaskill, "The Legacy of the Past: An Overview," in Indian Education in Canada, Volume 1: The Legacy, ed. Barman, Hébert and McCaskill (Vancouver: University of British Columbia Press, 1986); S. Brookes, "The Persistence of Native Education Policy in Canada," in The Cultural Maze: Complex Questions on Native Destiny in Western Canada, ed. J.W. Friesen (Calgary: Detselig, 1991); and B. Titley, "The Education of the Canadian Indian: The Struggle for Local Control," Journal of American Indian Education 20, no. 3 (1981): 18-24.

2 J.R. Miller, Shingwauk's Vision: A History of Native Residential Schools (Toronto: University of Toronto Press, 1996), 390. The policy favouring integration reflected developments in the United States where a "termination" policy was being pursued. See O. LaFarge, "Termination of Federal Supervision: Disintegration and the American Indians," Annals of the American Academy of Political and Social Science 311 (May 1957): 41-46.

3 Indian Act, 1951, section 113 (b). From 1951 until the early 1980s, the Canadian government essentially walked two paths. While actively promoting integrated schooling for on-reserve children seeking to be educated in off-reserve provincial schools, federal Indian Affairs authorities also continued to build and fund both onreserve day schools and residential schools, the last of which was closed in 1986.

4 See "Indian Segregation Must Go," The News-Herald, March 29, 1950, 4; and "Opening Our Schools to Indians," Victoria Daily Times, August 9, 1950, 4.

5 BC Archives (BCA) GR-1768, BC Ministry of Education, Deputies' Committee: Agendas and Minutes from Meetings - File: Schools Policy Committee Meetings. Minutes, 30 March 1981.

6 See, for example, Barman et al., "Legacy," 1986; Brookes, "Persistence of Native Education Policy," 1991; and Titley, "Struggle for Local Control," 1981.

7 B. Titley, A Narrow Vision: Duncan Campbell Scott and the Administration of Indian Affairs in Canada, (Vancouver: UBC Press, 1986).

8 J. Barman, "Families vs. Schools: Children of Aboriginal Descent in British Columbia Classrooms of the Late Nineteenth Century," in Family Matters: Papers in PostConfederation Canadian Family History, ed. E. Montigny and L. Chambers (Toronto: Canadian Scholars' Press, 1998), 74.

9 See N. Flood Davin, Report on Industrial Schools for Indians and Half-Breeds, Ottawa, $14^{\text {th }}$ March, 1879. 
10 Titley, Narrow Vision, 77.

11 Miller, Shingwauk's Vision, 103.

12 Dominion of Canada. Department of Indian Affairs (DIA) Annual Reports for the Year Ended $31^{\text {st }}$ December, 1914, 245.

13 Ibid.

14 Two Arrow Lake Band children attended public school at Burton and several others in New Westminster. One Aboriginal student, Harry Harris, was enrolled in Armstrong High School's matriculation class and was expected to succeed at his exam that summer. DIA Reports, 1915, 207.

15 DIA Reports, 1920, 15. In 1921, the figure was \$160.62. DIA Reports, 1921.

16 The increased figure may reflect the late 1920 amendment to the Indian Act compelling children between the ages of seven and fifteen to attend school. The highest figure $(\$ 6,717.80)$ for tuition fees was paid to Quebec in 1915. Second highest was Ontario at \$1,362.57. DIA Reports, 1915, 123.

17 "Indians Must Quit School," The Times, November 15, 1928.

18 E.A. Harris recalls that "during the 1930's the federal government withdrew its support of church mission schools and the assimilation of the native children into the provincial education system provided enough pupils for a two-room school for several years." Spokeshute: Skeena River Memory (Victoria: Orca Book Publishers, 1990), 123.

19 In 1933, the Liberal Party of Duff Pattullo defeated W.T. Tolmie's Conservatives on the promise of lowering taxes to alleviate some of the suffering brought on by the Depression. See "To Seek Dominion Aid for Creation of Work in British Columbia," The Times, November 24, 1933, 2; and "Education Costs," The Province, April 4, 1934 , 4. The $\$ 20$ per annum fee was changed to $\$ 35$ in 1944 . Letter of T.A. Crerar to H. Perry, December 11, 1944, cited in British Columbia School Trustees' Association, Proceedings of the Fortieth Convention, Vancouver, BC: BCSTA, September 25-27, 1944, 92. For a table of expenditures, see DIA Reports, 1933-34.

20 DIA Reports, 1934-35.

21 Annual Report of the Public Schools of British Columbia (ARPS), 1932-33, M40. For reasons unknown, this course only remained on the syllabus until 1935.

22 J. Barman, The West Beyond the West: A History of British Columbia (Toronto: University of Toronto Press, 1991), 297.

23 Special Joint Committee of the Senate and the House of Commons appointed to examine and consider the Indian Act (hereafter SJC). Minutes of the Proceedings and Evidence, No. 5 (Ottawa: Edmond Cloutier, 1946), 165.

24 See for example the testimony of R.A. Hoey, National Director of Indian Affairs, SJC, No. 5, 173.

25 Miller, Shingwauk's Vision, 418-419.

26 Public Archives of Canada (PAC) Indian Affairs, RG-10, Volume 6407, File 836-1, Part I. Letter of B.F. Neary, Superintendent of Welfare and Training to Major D.M. McKay, Indian Commissioner for BC, September 10, 1947. See also, ARPS 1963-64, N74.

27 This decision was strongly opposed by the New Hazelton Citizens Association who petitioned the Minister of Education on November 27, 1948 to allow them to separate from the Terrace school district. They argued that combining the two schools and situating the new one in the "heart of an Indian Reservation" was detrimental to children due to the distance most children would now need to travel and to the "degrading" environment surrounding the reserve. BCA GR-1222, Box 66, File 7, Education, Minister. In his memoirs, Keenleyside noted that some of the "most critical and emotionally entangling yet fascinating problems I had as Deputy Minister arose in the administration of Indian Affairs." Yet, he devoted just under two pages to Indian Affairs in a two-volume memoir totaling well over 1,000 pages. See H. Keenleyside, Memoirs of Hugh L. Keenleyside, Volume 2 - On the Bridge of Time (Toronto: McLelland \& Stewart Ltd., 1982). 
28 BCA GR-1955, Indices to Laws, Statutes and Orders-in-Council, 1872-1981. Orders-inCouncil numbers 441/49, 1749/50, 1937/50, 1939/50 and 2156/50. In 1951, Alberni, Nanaimo and Alert Bay were the next areas to integrate. Orders-in-Council numbers 563/51, 696/51 and 2673/51.

29 "Government Widens Plan to Recruit More Teachers: Stopgap Methods May Assist Rural Schools To Combat Shortage," Vancouver Sun, August 28, 1942, 17.

30 Province of BC. Report of the Commission of Inquiry into Educational Finance (Victoria: Charles Banfield, 1945), 4.

31 Ibid., 97.

32 ARPS, 1947-48, N28.

33 ARPS, 1948-49, N28. See also, "Prepared to Admit Indian Children into Education System of Province," Colonist, March 16, 1950, 7. "BC Schools Will Open to Indians," Sun, September 13, 1950, 2.

34 BCA GR-1071, Indian Advisory Committee Box 1: File 3. Letter of William T. Straith, Education Minister, to G.S. Pearson, Provincial Secretary.

35 Among the most notable Indian advocates were the Reverend Peter Kelly, an ordained minister of the United Church of Canada, Chief William Scow of Village Island, Chief Jimmie Sewid of Alert Bay and Bob Clifton of Hartley Bay. Advocacy groups such as the Canadian Civil Liberties Union and the Society for the Furtherance of British Columbia Indian Arts and Crafts had long been lobbying both the provincial and federal governments to develop more humane living conditions for Aboriginal peoples. A.P. Parminter, "The Development of Integrated School for British Columbia Indian Children" (Unpublished Master of Arts thesis, University of British Columbia, 1964). See also BCA, GR-0111, Museum Correspondence Inward, Box 11, File 1: D.M. McKay, Indian Commissioner.

36 BCA GR-1071, Indian Advisory Committee, File 9. Letter of Kelly to Doug Wilkinson, 22 November 1950. This increasing emphasis on citizenship was hastened by the federal adoption of Canada's first Citizenship Act in 1947.

37 BCA GR-1071, Indian Advisory Committee, File 8. Also, Government of British Columbia. Report of the Royal Commission on Education (Victoria: Queen's Printer, 1960), 257.

38 BCA GR-1071, Indian Advisory Committee, Box 1, File 8: 1951 Annual Report of the Provincial Advisory Committee on Indian Affairs from T.R. Kelly to J.H. Cates, Minister of Labour.

39 British Columbia School Trustees' Association (BCSTA), Proceedings of the Forty-Fifth Convention (Vancouver: BCSTA, September 12-14, 1949), 114.

40 Parminter, 1964, 78. Within ten years, the per pupil rate was raised to $\$ 365.20$ per year. See ARPS, 1960-61, 26.

41 This policy shift was greatly influenced by the testimony of Dominion anthropologist Diamond Jenness to the SJC in 1946. Jenness presented a "Plan for Liquidating Canada's Indian Problem Within 25 Years" that would merge Canada's native populations with other citizens. See SJC, Minutes, No. 7, Tuesday, March 25, 1947, 310-311. See also, Indian \& Northern Affairs, The Historical Development of the Indian Act (Ottawa: Indian \& Northern Affairs, 1978), 144, and J.F. Leslie, "Assimilation, integration or termination? The development of Canadian Indian policy, 1943-1963" (Unpublished $\mathrm{PhD}$ dissertation, Carleton University, 1999).

42 Topics included transportation, food, clothing and other aspects of west coast Indian life. A.F. Flucke, Indian Life in B.C., BC Teacher, October 1950, 58.

43 ARPS, 1951-2, N39.

44 H.B. Hawthorn, C.S. Belshaw, and S.M. Jamieson, The Indians of British Columbia (California: University of California Press, 1958), 290-91.

45 Ibid., 1964, 83. See also GR-1071, Indian Advisory Committee, Box 1: File 8. 1951 Annual Report. 
ARPS, 1949-50, 082. See also L.R. Peterson, "Indian Education in British Columbia" (Unpublished Master of Arts thesis, University of British Columbia, 1959), 115. By 1954, BC enrolled 1,488 students in its public and private schools. See R.F. Davey, "Education of Indians in Canada," Canadian Education, 10, no. 3 (1955): 36-37.

47 BCA GR-1071, Indian Advisory Committee Box 2 File 1. Minutes, 31 January, 1951. Letter of R.T. Kelly, Indian Advisory Committee Secretary to John Cates, BC Minister of Labor, 24 February, 1951. See also, BCA GR-1030, Home Economics Branch Records, 1919-1981, Circular of J.F.K. English, Deputy Minister and Superintendent to All District Superintendents, March 14, 1963.

48 Province, Report of Royal Commission, 257.

49 BCA MS-1290, Dr. J.D. Leechman, 1890-1980. Address of Ellen Fairclough, Minister of Citizenship and Immigration. Canadian Association of School Superintendents and Inspectors. Saskatoon, September 15, 1959.

50 The first such study was funded jointly in 1947 by the Canadian Social Science Research Council and the Indian Affairs Branch, led by Dr. Andrew Moore, Inspector of the Province's Secondary Schools. SJC, Minutes, No. 7, Tuesday, March 25, 1947.

51 PAC, RG-10, Vol. 6036, File: 150-144, Part I. Indian Affairs, School Files. Letter of N.W. Morton, Director of Operational Research, to B.F. Neary, Superintendent of Education, July 15, 1949.

52 "Elusive Indian Pupils Battle White Teachers," Colonist, October 3, 1958, 2.

53 PAC RG-10, Indian Affairs, School Files. Vol. 6036, File 150-144. Letter of BC Indian Schools Inspector to B.F. Neary, Superintendent of Education, March 3, 1949.

54 Ibid.

55 See L.R. Peterson, "Indian Education in British Columbia" (Unpublished Master of Arts thesis, University of British Columbia, 1959).

56 Ibid., 122.

57 John W. Friesen, "Some Philosophical Bases of Indian Educational Wants," The Journal of Education, 17 (April, 1971): 56-70. See also "Too Much Teacher Talk Blamed for 'Dull' Students," Province August 5, 1966, 21; and "Indian Dropouts Blamed on Whites," Vancouver Sun, August 14, 1968, 15.

58 H. Hawthorn, C. Belshaw, and S. Jamieson, The Indians of British Columbia (California: University of California Press, 1960), 304. Hawthorn was born in New Zealand and taught briefly for the Native School Service in Whatawhiwhi, a remote Maori community.

59 Ibid.

60 Testifying before the 1959-60 SJC, Dr. Peter Kelly argued that Aboriginal children's educational attainment had historically been hampered due to Aboriginal peoples' "habit of living." Kelly, a lay United Church minister and Haida leader who had attended Coqualeetza Institute implied that seasonal employment led to high family mobility rates and poor attendance. SJC, Minutes No. 6, July 2 and 3, 1959, 165.

61 F.H. Johnson, A History of Public Education in British Columbia (Vancouver: UBC Press, 1964), 137. It is important to note that this figure represented only a small percentage of the 50,549 school-aged Aboriginal children across Canada at the time. Approximately half of Canada's Aboriginal children continued to be schooled in residential and day schools. Initially, some Aboriginal leaders supported the continued development of residential schools. See Testimony of Frank Calder, Nisga'a Tribal Council, to the Joint Committee of the Senate and House of Commons on Indian Affairs, Minutes of Proceedings and Evidence, May 26-27, 1960, 604.

62 BCA GR-0152, BC Department of Education, 1960-61. Box 7, File 16: Indians. Province of BC, Eleventh Annual Report of the BC Indian Advisory Committee and of the Director, December 31, 1960.

63 BCA GR-1955, Indices, Order-in-Council \#2629, October 16, 1963. The agreement was negotiated in November 1963 but took effect retroactively to January 1963. 
64 BCA Add.MSS-2848, Jeffray Vincent Boys Collection, Box 3. D.B. Fields \& W.T. Stanbury, The Economic Impact of the Public Sector Upon the Indians of British Columbia: An Examination of the Incidence of Taxation and Expenditure of Three Levels of Government. Prepared for C.I. Fairholm, Director of Policy and Planning, Indian Affairs Branch, September 1968.

65 BCA MS-0449, Black, W.D., 1910-Box 5, File 11 - Federal-Provincial Relations, 1 June 1965, CKLN Radio Broadcast. Negotiations for transferring social welfare services to the provinces, with initial federal funding support, had begun in 1964 with the development of a Federal-Provincial Welfare Committee. BCA GR-0128, BC Department of Social Welfare, 1936-1966, Box 5, File 43, Indian Affairs.

66 BCA GR-0151, BC Department of Education, 1962-1968. See documentation for boxes 2, 4 and 17 .

67 Indian Affairs Branch, Federal-Provincial Conference on Indian Affairs: Report of Proceedings, October, 1964. The federal government's desire to review Indian Affairs policy was prompted in part by its desire to tackle poverty. See S. Brookes, "Analysis of Indian Education Policy" (Master of Arts thesis, University of Calgary, 1990), 62.

68 H. Hawthorn, ed., A Survey of the Contemporary Indians of Canada-Economic, Political, Educational Needs and Policies (Ottawa: Indian Affairs Branch, October 1967).

69 Ibid., 161-164.

70 See BCA GR-0151, Department of Education, Correspondence Files, 1962-1968. See correspondence of J. Phillipson, Assistant Superintendent, Administration and R.M. Hall, Regional School Superintendent, September to November, 1967 and Indian Affairs Branch, Choosing a Path: A Discussion Handbook for the Indian People (Ottawa: Indian Affairs Branch, 1967). See also "Indian Dropouts Blamed on Whites," The Vancouver Sun, March 14, 1968, 15. See also "The Needs of Students Are Not Being Met-Dailly's White Paper,” BC Teachers' Federation Newsletter, 13 (April 1974): 6.

71 This policy direction was most fully expressed in 1969 when Trudeau and his cabinet set out policy objectives for Indian Affairs. See Weaver, The Making of Indian Policy, 114-119. See also R.A. Sim, "Indian Schools for Indian Children," in The Best of Times/The Worst of Times: Contemporary Issues in Canadian Education, H. Stevenson, R. Stamp, and J.D. Wilson, eds. (Toronto: Holt, Rinehart, Winston, 1972), 112.

72 Standing Committee on Indian and Northern Affairs, Minutes of Proceedings, 1968, 916.

73 Ibid., 924.

74 Evidence suggests that not all native parents were pleased with this development, claiming that they had been stripped of their traditional right to choose between public and private or religious schooling. Standing Committee, Minutes, No. 25, May 20, 1969, 887. Although the fee was increased regularly over time, it was not until 1988 that the MTA was significantly revised to enable the federal government to bypass the province and route funds directly to native band councils who, in turn, purchased services for on-reserve children from local school districts. BC Ministry of Education Records, Accession \#91-2708, Anthony Brummet, Box 37, File 3590-1: Special Education: Native Indians. Opposition to the MTA began as early as 1974. See "School Boycott by Indians Delayed by Federal Talks," Province, September 18, 1974, 8. UBCIC Understanding the Master Tuition Agreement (Vancouver: UBCIC, 1975).

75 Interview with Les Canty, November 7, 2006.

76 M. Ashworth, The Forces Which Shaped Them (Vancouver: New Star Books, 1979), 51.

77 ARPS, 1969/70, G120.

78 Standing Committee on Indian Affairs and Northern Development, Minutes No. 7 , November 29, 1968, 132.

79 Although the onus remained with districts to request provincial funding for such services, it was not uncommon for the Deputy Minister to "remind" recalcitrant 
districts that they were responsible for ensuring educational equity among their native populations. Interview with Les Canty, November 7, 2006.

80 ARPS, 1969-1970, G51. Information on native peoples had also figured prominently in the Teaching Program and Source Book for Canada's Centenary "THEN and NOW" 1867-1967, issued to teachers by the Minister of Education in 1966. BCA NW971.58 B863, MOE Curriculum Guides and Related Publications, 1914-1980.

81 Ibid. Other notable initiatives included the appointment of an Indian education coordinator in North Vancouver, a home-school coordinator at Lillooet, invitations from Howe Sound School Board for the local band council to attend board meetings and the Duncan School Board's authorization for University of Victoria professors to undertake a research study. See ARPS, 1970-71, C24.

82 Indian \& Northern Affairs, Canada, The Canadian Indian-Statistics (Ottawa: Indian and Northern Affairs, 1973), 50; Indian and Northern Affairs, Canada, The Canadian Indian-A Brief Outline (Ottawa: Indian and Northern Affairs, 1973); and Barman, The West Beyond the West, 308.

83 "Indian Students Lag in English," The Vancouver Sun, June 13, 1969, 16.

84 "Steal Identity, Destroy Man," Daily Colonist, January 21, 1970, 22; "Indian Control of Schools Urged as Delegates Cite Government Failure," The Vancouver Sun, May 28, 1970, 10; "Schools Criticized," Daily Colonist, November 1, 1970, 23; "Special Education for Indians Urged," The Vancouver Sun, May 10, 1970, 31; and "Indians in Schools 'Need Understanding," The Vancouver Sun, December 10, 1971, 25.

85 Department of Indian Affairs and Northern Development, Canada, Indian Education In Canada (Toronto: DIAND, Education Division, 1973); "System Seen Hurting Indians in Schools," The Times, November 3, 1971, 31; "Why Young Indians Give Up," The Vancouver Sun, May 25, 1970, 11; "Indian School Dropout Casualties 90\%," The Times, September 22, 1971, 3; "Teachers Urged to Study Indians," The Vancouver Sun, May 17, 1972, 17; "Education System Must Change," The Vancouver Sun, November 8, 1972, 19; "Schools Fail, Not Indians Claims Former Principal," The Times, November 8, 1972, 24; and "System Blamed for Indians' Failure," The Colonist, September 21, 1973, 20.

86 DIA Reports, 1969-70, 131.

87 "Indian School Dropout Casualties 90\%," The Times, September 22, 1971, 3.

88 F.H. Johnson, A History of Education in British Columbia-amended manuscript, 269 (held at UBC library).

89 "Special Deals Out - Calder Hits Indian Policy," Daily Colonist, March 11, 1971, 36.

90 Debates of the Legislative Assembly of British Columbia, July 15, 1973, 461.

91 "Indian Control of Schools Urged as Delegates Cite Gov't Failure, Vancouver Sun, May 28, 1970, 10.

92 W.T. Stanbury, "Reserve and Urban Indians in British Columbia: A Social and Economic Profile,” BC Studies, no. 26 (Summer 1975): 39. Reasons for this lack of BCbased data were two-fold. First, until 1969, the province considered integration to be a local issue, but districts lacked the resources to undertake the research. Second, federal officials, having divested themselves of responsibility for students educated off reserve, were "reluctant to follow the youngsters into the provincial schools because it creates the impression that we are responsible for them, and since we cannot control the provincial program, of course we cannot be responsible for it." Testimony of Mr. Davey to the Standing Committee on Indian Affairs, Minutes, May 23, 1969, 906.

93 See "How Our Schools Are Teaching Indians to Become Failures," Vancouver Sun, March 17, 1973, 6.

94 In Spolsky's words, the "striking disparity between the language of the pupils and of the teachers is clearly basic to the failure of Navajo education. Bilingual education has become a pressing need for Navajo schools; without it, Navajo students are doomed 
to inferior education.” B. Spolsky, Advances in Navajo Bilingual Education, 1969-72 (Albuquerque: American Bureau of Indian Affairs, 1973), 1.

95 "How Our Schools Are Teaching Indians to Become Failures," Vancouver Sun, March $17,1973,6$.

96 BCA MS-2209, Educational Research Institute of BC, 1956-1986, Report no. 68:4; C. Galloway, N. Mickelson, D. Burchfield, Orientation, Pre-school and Pre-kindergarten Summer Program for Indian Children (University of Victoria, July 1968). Between 1968 and its closure in 1986, the Institute funded eleven such projects.

97 J.L. Granatstein, ed., Twentieth Century Canada, (Toronto: McGraw-Hill Ryerson, 1986), 397. See also Barman, The West Beyond the West, 311. See also S. Weaver, The Making of Indian Policy, 1981.

98 Barman, The West Beyond the West, 311; Barman, Hébert and McCaskill, Indian Education in Canada. Volume 1, 15; J. Friesen, Rediscovering the First Nations of Canada (Calgary: Detselig Enterprises Limited, 1997), 231; and Katherine Graham, Public Policy and Aboriginal Peoples. Volume 1: Soliloquy and Dialogue: Overview of Major Trends in Public Policy Relating to Aboriginal Peoples (Ottawa: Minister of Public Works and Government Services of Canada, 1996), 273.

99 Union of BC Indian Chiefs, Progress Report (Vancouver: UBCIC, 1971), 3.

100 Friesen, Rediscovering, 231; and J.L. Tobias. "Protection, Civilization, Assimilation: An Outline History of Canada's Indian Policy, in Sweet Promises: A Reader on Indian-White Relations in Canada, J.R. Miller, ed. (Toronto: University of Toronto Press, 1991), 141.

101 H. Cardinal, The Unjust Society (Edmonton: M.G. Hurtig Publishers, 1969), 87.

102 Indian Chiefs of Alberta, Citizens Plus, A Presentation to Right Honourable P.E. Trudeau, June 1970.

103 Graham, Public Policy and Aboriginal Peoples, 278.

104 Ibid.; C. Haig-Brown, Resistance and Renewal-Surviving the Indian Residential Schools (Vancouver: Tillacum Library, 1988), 120.

105 National Indian Brotherhood, Indian Control of Indian Education (Ottawa: NIB, 1972), 25-26.

106 Haig-Brown, Resistance and Renewal, 120.

107 I am thankful to Dr. Saul Arbess for participating in an interview October 11, 2006. Arbess was the Director of Indian Education for the Ministry of Education from 1976 to 1983 .

108 BCA - GR1561, Files of Andy Soles, BC Ministry of Education. An address by the Honourable Eileen Dailly, Minister of Education, to the B.C.T.F. Vancouver, B.C., March 31, 1975.

109 "Dailly Wants Centres for Education - Indian Control," Daily Colonist, November 9, 1972. Minutes of the Legislative Assembly of BC, September 18, 1973, 61-66.

110 Ashworth, The Forces Which Shaped Them, 51; ARPS, 1976-77, 21. Earlier that year, Wilson had been rebuffed by the Department of Education when, as president of the Native Indian Teachers Association, he presented a proposal to fund a native teacher education program. The department allegedly refused arguing that it was discriminatory on the basis of race.

111 ARPS, 1973-4, D39. See also Debates of Legislative Assembly of BC, 14 January, 1973,428 . One of the key priorities for the district was support for Nisga'a language development followed by English language instruction. I am thankful to Jack Fleming, former Deputy Minister of Education, for an interview, January 8, 2007.

112 D. Sanders, "The Nisga' Case," BC Studies, 19 (Autumn 1973): 18.

113 Debates of the Legislative Assembly of British Columbia, February 20, 1974, 349.

114 BCA GR-1561, Files of Andy Soles, Box 4. Briefing notes: Seth Halton, August 29, 1974. See also, Ashworth, Forces Which Shaped Them, 51.

115 BCA MS-2209, Educational Research Institute of BC, 1956-1986, Report no. 75:19. Report of the BC Native Indian Teachers Association Spring Conference, April 2-4, 1975. 
116 BC School Trustees Association (BCSTA) Dailly to Madson, President, in response to BCSTA. Recommendations for Indian Education, July 30, 1974. In 1974, the University of British Columbia enrolled its first teachers into its newly-developed Native Indian Teacher Education Program (NITEP) after the new Dean of Education had invited proposals for alternative education programs in 1973. Unfortunately, of the sixty students who entered the program, only fourteen continued on to their third year by 1976.

117 Minutes of the BC Legislative Assembly, March 20, 1974, 1428.

118 Minutes of the BC Legislative Assembly, May 28, 1974, 3476.

119 ARPS, 1973-74, D32.

120 BCA G81-056, Education Minister, 1975-1979. The Nishga People, Citizens-Plus, 1975.

121 Leo temporarily held the position after the untimely death of George Wilson in 1975.

122 Interview with Dr. Saul Arbess, October 11, 2006.

123 BCA G81-056, Education Minister, 1975-1979. "To Feed Native Children,” News, December $1,1976$.

124 ARPS, 1976-77, 21.

125 The next few paragraphs recounting initiatives undertaken by the Ministry are based on information provided during an interview with Dr. Arbess, October 11, 2006.

126 ARPS, 1978-79.

127 Province of British Columbia, New Strategies in Indian Education: Utilizing the Indian Child's Advantages in the Elementary Classroom (Victoria: Indian Education Branch, 1981).

128 BCA G81-056, Education Minister, 1975-1979. Hardwick to McGeer, January 9, 1979.

129 Ibid.

130 Province of British Columbia, Education: A Report from the Minister (Victoria: BC Ministry of Education, 1981), 2.

131 Ibid., 24.

132 BCA GR-1768, BC MOE, Deputies' Committee: Agendas and Minutes, March 30, 1981.

133 BC Ministry of Education, Deputies' Committee: Agendas and Minutes from Meetings, March 30, 1981. BCA 1768, File: Schools Policy Committee Meetings Minutes.

134 "Study Says Natives Serve Selves Best," Sun, July 5, 1983, B8. See also, "BC Scores an F for its Improved Indian Education," Province, June 17, 1983, A1.

135 R. Manzer, Public Schools and Political Ideas: Canadian Educational Policy in Historical Perspective (Toronto: University of Toronto Press, 1994), 4.

136 L. Downey, Policy Analysis in Education (Calgary: Detselig, 1988).

137 Indeed, both Leslie Peterson and Donald Brothers, Ministers of Education during the 1960 s, turned down requests to be interviewed, stating that they were not involved in any negotiations with Indian Affairs.

138 See Titley, Struggle for Local Control, 20, and Brookes, Persistence of Native Education Policy, 170.

139 The term "equality revolution" is borrowed from Barman in The West beyond the West, chapter 13, 297-321. The "revolution" occurred within a larger Canadian context whereby the role of the post-war state had shifted from an emphasis on protection of social order and economic progress to the promotion of individual human rights. See R. Manzer, Public Policies and Political Development in Canada (Toronto: University of Toronto Press, 1985), 179.

140 S.J. Berkhout and W. Wielemans, "Understanding Educational Policy: An Integrative Approach,” Educational Policy, 13, no. 3 (July 1999): 402-420. 
141 J. G. Delaney, Educational Policy Studies (Calgary: Detselig, 2002), 62. See also R. Weatherly and M. Lipsky, "Street-level bureaucrats and institutional innovation: Implementing special education reform," Harvard Educational Review, 47, no. 2 (1977): 171-197.

142 The gap between governance of central authorities and administration by local officials was exacerbated in 1958 when the provincial inspectors-government's "boys in the field"-became district superintendents. In 1974, inspectors in the province's largest districts were no longer provincial employees, but were hired by local boards and by 1981 , all superintendents were locally hired, shifting their allegiance from the province to their local boards. See T. Fleming, "'Our Boys in the Field': School Inspectors, Superintendents, and the Changing Character of School Leadership in British Columbia," in N.M. Sheehan, J. D. Wilson, and D.C. Jones (eds.), Schools in the West: Essays in Canadian Educational History (Calgary: Detselig, 1986), 285-303.

143 L.W. Koenig, An Introduction to Public Policy (Englewood Cliffs, NJ: Prentice Hall, 1986), 149.

144 "Schooling Natives," Globe and Mail, July 6, 2006, A14. 